\title{
Cytotoxic Coumarins from the Bark of Mammea siamensis
}

\author{
Ngoc Trang Nhu NGo, ${ }^{a, b}$ Vy Thuy NGuyen, ${ }^{c}$ Hoa Van Vo, ${ }^{a}$ Ole VAng, ${ }^{*, b}$ Fritz Duus,${ }^{b}$ \\ Thuy-Duong Huynh Ho, ${ }^{c}$ Hung Dinh Pham, ${ }^{a}$ and Lien-Hoa Dieu NGUYeN ${ }^{a}$ \\ ${ }^{a}$ Natural Products and Medicinal Chemistry Laboratory, Faculty of Chemistry, Ho Chi Minh City University of Science; \\ ${ }^{c}$ Department of Genetics, Faculty of Biology, Ho Chi Minh City University of Science; 227 Nguyen Van Cu, Ho Chi Minh \\ City, Vietnam: and ${ }^{b}$ Department of Science, Systems and Models, Roskilde University; P.O. Box 260, DK-4000, Roskilde, \\ Denmark. $\quad$ Received June 1, 2010; accepted August 25, 2010; published online September 1, 2010
}

A new geranylated coumarin, (E)-4-(1-hydroxypropyl)-5,7-dihydroxy-6-(3,7-dimethyl-2,6-octadienyl)-8-(3methyl-1-oxobutyl)coumarin (named surangin D), was isolated from the bark of Mammea siamensis collected in Vietnam, along with four known coumarins, surangins B and C, and theraphins B and C, and seven xanthones, 1,7-dihydroxyxanthone, 7-hydroxy-1-methoxyxanthone, 1,7-dimethoxyxanthone, 1,7-dimethoxy-6-hydroxyxanthone, 1,6,7-trihydroxyxanthone, 1,3,7-trihydroxyxanthone, and 1,7-dihydroxy-3-methoxyxanthone. Their structures were determined by spectroscopic methods (mainly 1D- and 2D-NMR) and preparation of methylated derivatives. The four coumarins, surangins $C$ and $D$ and theraphins $B$ and $C$, were tested for inhibition of cell proliferation in DLD-1 (colon cancer), MCF-7 (breast adenocarcinoma), HeLa (human cervical cancer) and NCIH460 (human lung cancer) cell lines using the sulforhodamine B (SRB) assay. In all four cell lines, theraphin C showed the strongest activity $\left(\mathrm{IC}_{50}\right.$ in the range of $\left.1.6-5.7 \mu \mathrm{M}\right)$. Testing the anti-proliferative effect of the methylated derivatives showed reduced cellular effects of all derivatives, indicating that the number and position of free hydroxyl groups were very important for the anti-proliferative effect.

Key words Mammea siamensis; Guttiferae; surangin D; coumarin; xanthone; cell proliferation

The genus Mammea (Guttiferae) consists of about 30 species, found in Southeast Asia, Africa and Western India. ${ }^{1,2)}$ In traditional medicine, the flowers of Mammea siamensis are used as a heart tonic whilst the flower buds of Mammea longifolia are chewed after heavy meals to improve digestion. ${ }^{3)}$ Earlier studies have shown that the genus is a rich source of coumarins and xanthones, some of which have potential pharmacological and therapeutic properties. ${ }^{4-9)} \mathrm{We}$ here report the chemical constituents of the bark of Mammea siamensis collected in south Vietnam with the isolation of a new and four known coumarins as well as seven xanthones. In addition, new data on the anti-proliferative activity of the coumarins surangins $\mathrm{C}-\mathrm{D}$ and theraphins $\mathrm{B}-\mathrm{C}$ and their methylated derivatives were generated using sulforhodamine B (SRB) assay on four human cancer cell lines, MCF-7 (breast adenocarcinoma), HeLa, DLD-1 (colon cancer) and NCI-H460 (human lung cancer).

\section{Results and Discussion}

A petroleum ether extract of the bark of Mammea siamensis was subjected to silica gel, $\mathrm{RP}_{18}$ and Sephadex LH-20 to afford a new coumarin, surangin D (1), four known coumarins, surangin $\mathrm{C}(\mathbf{2}),{ }^{10)}$ theraphin $\mathrm{B}(\mathbf{3}),{ }^{10)}$ theraphin $\mathrm{C}$ $(4)^{10)}$ and surangin B (5) ${ }^{3)}$ (Fig. 1), and four xanthones, 1,7dihydroxyxanthone (6), ${ }^{11)}$ 7-hydroxy-1-methoxyxanthone (7), 1,7-dimethoxyxanthone (8), ${ }^{5)}$ and 1,7-dimethoxy-6-hydroxyxanthone (9) ${ }^{12)}$ (Fig. 2). Similarly, the ethyl acetate extract furnished three xanthones comprising 1,6,7-trihydroxyxanthone (10), 1,3,7-trihydroxyxanthone (11) and 1,7-dihydroxy-3-methoxyxanthone (12) (Fig. 2). ${ }^{13)}$ In addition, treatment of the coumarins $\mathbf{1}-\mathbf{4}$ with $\mathrm{CH}_{3} \mathrm{I}$ and $\mathrm{K}_{2} \mathrm{CO}_{3}$ in acetone produced ten methylated derivatives $(\mathbf{1 a}-\mathbf{1 d}, \mathbf{2} \mathbf{a}-\mathbf{2 b}, \mathbf{3 a}-$ 3b, 4a-4c) (Fig. 1).

Compound $\mathbf{1}$ was obtained as a yellowish gum and gave a positive test with methanolic ferric chloride, indicating its phenolic nature. High resolution (HR)-electrospray ioniza-
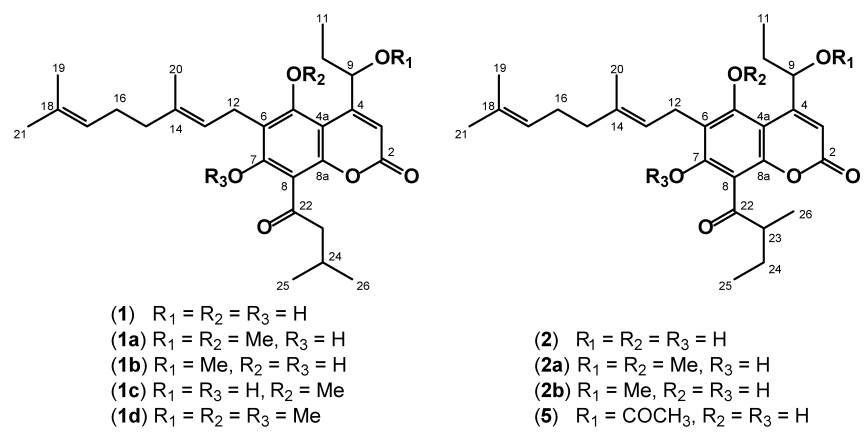

$$
\begin{aligned}
& \text { (1a) } R_{1}=R_{2}=M e, R_{3}=H \\
& \text { (1b) } R_{1}=M e, R_{2}=R_{3}=H \\
& \text { (1c) } R_{1}=R_{3}=H, R_{2}=M e \\
& \text { (1d) } R_{1}=R_{2}=R_{3}=M e
\end{aligned}
$$

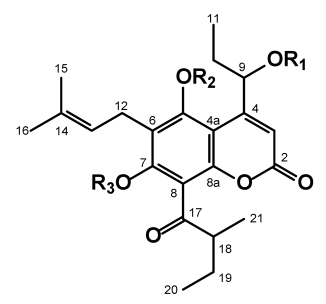

(3) $\mathrm{R}_{1}=\mathrm{R}_{2}=\mathrm{R}_{3}=\mathrm{H}$ (3a) $R_{1}=R_{2}=M e, R_{3}=H$ (3b) $R_{1}=M e, R_{2}=R_{3}=H$
(2) $R_{1}=R_{2}=R_{3}=H$ (2a) $R_{1}=R_{2}=M e, R_{3}=H$ (5) $\mathrm{R}_{1}=\mathrm{COCH}_{3}, \mathrm{R}_{2}=\mathrm{R}_{3}=\mathrm{H}$

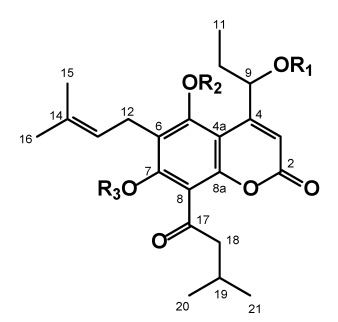

(4) $\mathrm{R}_{1}=\mathrm{R}_{2}=\mathrm{R}_{3}=\mathrm{H}$

(4a) $R_{1}=R_{2}=M e, R_{3}=H$ (4b) $R_{1}=M e, R_{2}=R_{3}=H$ (4c) $R_{1}=R_{3}=H, R_{2}=M e$ (2b) $R_{1}=M e, R_{2}=R_{3}=H$

Fig. 1. Structures of Coumarins $\mathbf{1}-\mathbf{5}$ and Their $O$-Methylated Derivatives $(1 \mathrm{a}-4 \mathrm{c})$

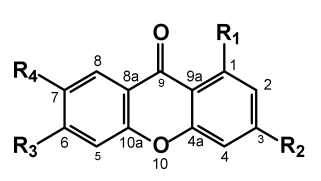

(6) $\mathrm{R}_{1}=\mathrm{R}_{4}=\mathrm{OH}, \mathrm{R}_{2}=\mathrm{R}_{3}=\mathrm{H}$

(7) $\mathrm{R}_{1}=\mathrm{OMe}, \mathrm{R}_{2}=\mathrm{R}_{3}=\mathrm{H}, \mathrm{R}_{4}=\mathrm{OH}$

(8) $\mathrm{R}_{1}=\mathrm{R}_{4}=\mathrm{OMe}, \mathrm{R}_{2}=\mathrm{R}_{3}=\mathrm{H}$

(9) $\mathrm{R}_{1}=\mathrm{R}_{4}=\mathrm{OMe}, \mathrm{R}_{2}=\mathrm{H}, \mathrm{R}_{3}=\mathrm{OH}$

(10) $R_{1}=R_{3}=R_{4}=O H, R_{2}=H$

(11) $R_{1}=R_{2}=R_{4}=O H, R_{3}=H$

(12) $R_{1}=R_{4}=O H, R_{2}=O M e, R_{3}=H$

Fig. 2. Structures of Xanthones 6-12

tion (ESI)-MS showed the molecular formula to be $\mathrm{C}_{27} \mathrm{H}_{36} \mathrm{O}_{6}$ $\left(\mathrm{m} / \mathrm{z} 457.2585[\mathrm{M}+\mathrm{H}]^{+}\right)$, i.e. the molecule had ten units of unsaturation. The IR [ $v_{\max } 1739$ (lactone carbonyl), 1708 (conjugated carbonyl), $\left.1580(\mathrm{C}=\mathrm{C}) \mathrm{cm}^{-1}\right]$ and $\mathrm{UV}\left(\lambda_{\max }\right.$ 
$223,297,325 \mathrm{~nm}$ ) spectra were similar to those of 5,7-dioxygenated coumarins. ${ }^{14)}$

The ${ }^{1} \mathrm{H}-\mathrm{NMR}$ spectrum of $\mathbf{1}$ (Table 1 ) showed resonances for a chelated hydroxyl group $\left(\delta_{\mathrm{H}} 14.37\right)$, two olefinic protons $\left(\delta_{\mathrm{H}} 5.19\right.$ and 5.06), a deshielded oxygenated proton $\left(\delta_{\mathrm{H}}\right.$ 4.66), and a singlet signal typical of $\mathrm{H}-3$ in the coumarin skeleton $\left(\delta_{\mathrm{H}} 6.01\right)$, indicating that $\mathrm{C}-4$ was substituted. There were also signals due to a primary $\left(\delta_{\mathrm{H}} 1.05, \mathrm{t}\right)$, two secondary $\left(\delta_{\mathrm{H}} 1.00\right.$ and $0.99, \mathrm{~d}$ each $)$ and three vinyl methyls $\left(\delta_{\mathrm{H}}\right.$ $1.80,1.64$ and $1.57, \mathrm{~s}$ each) as well as five methylenes. The low field signal at $\delta_{\mathrm{H}} 14.37$ indicated a strong intramolecular hydrogen bond of the 7-OH proton and the adjacent carbonyl oxygen. The ${ }^{13} \mathrm{C}-\mathrm{NMR}$ spectrum (Table 1 ) revealed the presence of 27 carbons, comprising a ketone and a coumarin carbonyl carbon ( $\delta_{\mathrm{C}} 205.0$ and 160.6 , respectively), three trisubstituted carbon-carbon double bonds, six substituted aromatic carbons, an oxygenated methine, an $s p^{3}$ methine, five methylenes and six methyls.

Analysis of the 1D-NMR spectra and heteronuclear multiple bond connectivity (HMBC) correlations (Table 1, Fig. 3) showed that the molecule contained a geranyl, a 3-methyl-1oxobutyl and a 1-hydroxypropyl group. In the HMBC plot, $\mathrm{H}-3\left(\delta_{\mathrm{H}} 6.01\right)$ gave cross-peaks to $\mathrm{C}-2\left(\delta_{\mathrm{C}} 160.6\right), \mathrm{C}-4 \mathrm{a}\left(\delta_{\mathrm{C}}\right.$ $100.6)$ and the oxygenated methine $\left(\delta_{\mathrm{C}} 78.1\right)$ of the 1-hydroxypropyl side chain, revealing that the side chain was bonded to $\mathrm{C}-4$. This was supported by the correlations of $\mathrm{H}_{2}$ 10 with $\mathrm{C}-4$ and $\mathrm{H}-9$ with $\mathrm{C}-3$ and C-4a.

Table 1. ${ }^{1} \mathrm{H}-(500 \mathrm{MHz})$ and ${ }^{13} \mathrm{C}-\mathrm{NMR}(125 \mathrm{MHz})$ Data and HMBC Correlations for Surangin D (1) in $\mathrm{CDCl}_{3}$ ( $J$ in $\mathrm{Hz}$ in Parentheses)

\begin{tabular}{|c|c|c|c|c|}
\hline \multirow{2}{*}{ No. } & \multirow{2}{*}{$\delta_{\mathrm{H}}$} & \multicolumn{2}{|c|}{ HMBC correlations } & \multirow{2}{*}{$\delta_{\mathrm{C}}$} \\
\hline & & $J^{2}$ & $J^{3}$ & \\
\hline 2 & & & & 160.6 \\
\hline 3 & $6.01(\mathrm{~s})$ & $\mathrm{C}-2$ & C-4a, C-9 & 108.8 \\
\hline 4 & & & & 156.8 \\
\hline $4 a$ & & & & 100.6 \\
\hline 5 & & & & 157.7 \\
\hline 6 & & & & 114.6 \\
\hline 7 & & & & 166.8 \\
\hline 8 & & & & 104.0 \\
\hline $8 \mathrm{a}$ & & & & 156.2 \\
\hline 9 & $4.66 \mathrm{t}(6.5)$ & $\mathrm{C}-10$ & $\mathrm{C}-3, \mathrm{C}-4 \mathrm{a}, \mathrm{C}-11$ & 78.1 \\
\hline \multirow[t]{2}{*}{10} & $1.92 \mathrm{~m}$ & $\mathrm{C}-11$ & C-4, C-9 & 27.7 \\
\hline & $1.77 \mathrm{~m}$ & $\mathrm{C}-11$ & & \\
\hline 11 & $1.05 \mathrm{t}(5.5)$ & $\mathrm{C}-10$ & C-9 & 10.5 \\
\hline \multirow[t]{2}{*}{12} & $3.40 \mathrm{dd}(14.5,7.0)$ & $\mathrm{C}-6, \mathrm{C}-13$ & C-5, C-7, C-14 & 22.0 \\
\hline & $3.35 \mathrm{dd}(14.5,7.0)$ & C- $6, \mathrm{C}-13$ & $\mathrm{C}-5, \mathrm{C}-7, \mathrm{C}-14$ & \\
\hline 13 & $5.19 \mathrm{~m}$ & $\mathrm{C}-12$ & $\mathrm{C}-6, \mathrm{C}-15, \mathrm{C}-20$ & 121.2 \\
\hline 14 & & & & 136.8 \\
\hline 15 & $1.98 \mathrm{~m}$ & C-14, C-16 & $\mathrm{C}-13, \mathrm{C}-17$ & 39.8 \\
\hline 16 & $2.05 \mathrm{~m}$ & $\mathrm{C}-15, \mathrm{C}-17$ & $\mathrm{C}-14, \mathrm{C}-18$ & 26.7 \\
\hline 17 & $5.06 \mathrm{~m}$ & & C-19, C-21 & 124.3 \\
\hline 18 & & & & 131.3 \\
\hline 19 & $1.57 \mathrm{~s}$ & $\mathrm{C}-18$ & $\mathrm{C}-17, \mathrm{C}-21$ & 17.6 \\
\hline 20 & $1.80 \mathrm{~s}$ & $\mathrm{C}-14$ & C-13, C-15 & 16.2 \\
\hline 21 & $1.64 \mathrm{~s}$ & $\mathrm{C}-18$ & $\mathrm{C}-17, \mathrm{C}-19$ & 25.6 \\
\hline 22 & & & & 205.0 \\
\hline \multirow[t]{2}{*}{23} & $3.02 \mathrm{dd}(14.0,6.5)$ & $\mathrm{C}-22, \mathrm{C}-24$ & $\mathrm{C}-25, \mathrm{C}-26$ & 53.7 \\
\hline & $2.90 \mathrm{dd}(14.0,6.5)$ & $\mathrm{C}-22, \mathrm{C}-24$ & $\mathrm{C}-25, \mathrm{C}-26$ & \\
\hline 24 & $2.20 \mathrm{~m}$ & & & 25.3 \\
\hline 25 & $1.00 \mathrm{~d}(5.0)$ & $\mathrm{C}-24$ & $\mathrm{C}-23, \mathrm{C}-26$ & $22.6^{a)}$ \\
\hline 26 & $0.99 \mathrm{~d}(5.0)$ & $\mathrm{C}-24$ & $\mathrm{C}-23, \mathrm{C}-25$ & $22.7^{a)}$ \\
\hline $7-\mathrm{OH}$ & $14.37 \mathrm{~s}$ & $\mathrm{C}-7$ & C- 6, C-8 & \\
\hline
\end{tabular}

a) Interchangeable.
The chelated hydroxyl proton correlated to an oxygenated $\left(\delta_{\mathrm{C}} 166.8\right)$ and two substituted aromatic carbons $\left(\delta_{\mathrm{C}} 114.6\right.$ and 104.0). The oxygenated carbon therefore had to be C-7 which carried the hydroxyl group. HMBC correlations of the benzylic methylene protons of the geranyl group with $\mathrm{C}-7$, the first substituted aromatic carbon and an oxygenated aromatic carbon $\left(\delta_{\mathrm{C}} 157.7\right)$ showed that the geranyl side chain was attached to $\mathrm{C}-6$ or $\mathrm{C}-8$. In order to identify the location of the side chain, 1 was treated with $\mathrm{CH}_{3} \mathrm{I}$ and $\mathrm{K}_{2} \mathrm{CO}_{3}$ in acetone, which gave four $O$-methylated derivatives $(\mathbf{1 a}-\mathbf{1 d})$. In the HMBC spectrum of the fully $O$-methylated product 1 d, protons of the two methoxyl groups at $\delta_{\mathrm{H}} 3.78$ and 3.76 gave cross-peaks to two oxygenated aromatic carbons $\left(\delta_{\mathrm{C}} 158.4\right.$ and 156.9 , respectively) which had to be the carbons carrying the methoxyl groups. The two groups were thus bonded to $\mathrm{C}$ 7 and C-5. The benzylic methylene protons of the geranyl group correlated to C-7, C-5 and a substituted aromatic carbon $\left(\delta_{\mathrm{C}} 126.3\right)$. The geranyl group was therefore attached to C-6 and the 3-methyl-1-oxobutyl was deduced to be bonded to $\mathrm{C}-8$. Compound 1 was consequently the novel $(E)-4-(1-h y-$ droxypropyl)-5,7-dihydroxy-6-(3,7-dimethyl-2,6-octadienyl)8-(3-methyl-1-oxobutyl)coumarin which is named surangin D. Comparison of the ${ }^{1} \mathrm{H}$ - and ${ }^{13} \mathrm{C}-\mathrm{NMR}$ chemical shifts of the side chain at $\mathrm{C}-4$ in $\mathbf{1}$ with those of kayeassamins $\mathrm{A}$ and $\mathrm{B}^{14)}$ which have similar structures reveals that the shifts are very close. Furthermore the signs of specific rotation are opposite, the chiral center C-9 is therefore assumed to have opposite stereochemistry, i.e. having the $R$ configuration.

The methylated derivatives were determined by comparison of their 1D-NMR spectra with those of the parental compounds. Resonances for methoxyl groups derived from phenolic hydroxyls always appeared at lower fields $\left(\delta_{\mathrm{H}} 3.79\right.$ $\left.3.80 ; \delta_{\mathrm{C}} 62.3-63.0\right)$ while those from alcoholic hydroxyls had signals at higher fields $\left(\delta_{\mathrm{H}} 3.37-3.52 ; \delta_{\mathrm{C}} 57.9\right)$. Thus, the structures of the methylated derivatives was assigned as 5,9-di-O-methyl surangin D (1a), 9-O-methyl surangin D (1b), 5- $O$-methyl surangin D (1c), 5,7,9-tri- $O$-methyl surangin $\mathrm{D}$ (1d), 5,9-di-O-methyl surangin $\mathrm{C}$ (2a), 9-O-methyl surangin $\mathrm{C}$ (2b), 5,9-di- $O$-methyl theraphin B (3a), 9- $O$ methyl theraphin B (3b), 5,9-di-O-methyl theraphin C (4a), 9-O-methyl theraphin $\mathrm{C}(\mathbf{4 b})$ and 5-O-methyl theraphin $\mathrm{C}$ (4c).

The effect on the cell number of $\mathbf{1}-\mathbf{4}$ towards four human cancer cell lines, DLD-1, MCF-7, HeLa and NCI-H460 cells, was performed using SRB assay ${ }^{15)}$ and the results were expressed as $\mathrm{IC}_{50}$ values after $48 \mathrm{~h}$ of exposure of the compounds to the human cells (Table 2). Compound $\mathbf{1}-\mathbf{4}$ exhibited strong reduction in cell number against DLD-1 cell line with $\mathrm{IC}_{50}$ values in the range of $1.6-6.5 \mu \mathrm{M}$. No change of cell morphology of DLD-1 cells was observed around their

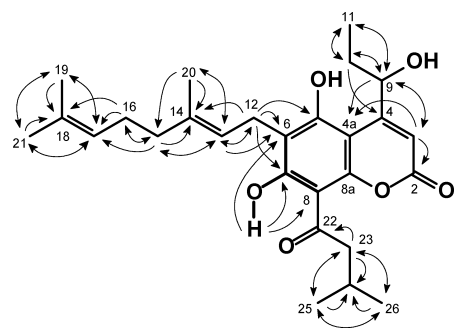

Fig. 3. HMBC Correlations for $\mathbf{1}$ 
Table 2. Cell Number Inhibitory Effects in Vitro of $\mathbf{1}-\mathbf{4}$

\begin{tabular}{ccccc}
\hline \hline \multirow{3}{*}{ Compound } & \multicolumn{4}{c}{$\mathrm{IC}_{50}(\mu \mathrm{M})$} \\
\cline { 2 - 5 } & \multirow{2}{*}{ DLD-1 } & HeLa & MCF-7 & NCI-H460 \\
\hline \multirow{2}{*}{$\mathbf{2}$} & $4.7 \pm 0.3$ & $13.6 \pm 0.4$ & $13.7 \pm 1.11$ & $23.8 \pm 1.5$ \\
$\mathbf{2}$ & $5.3 \pm 0.2$ & $4.7 \pm 0.1$ & $3.8 \pm 0.18$ & $8.99 \pm 0.10$ \\
$\mathbf{4}$ & $6.5 \pm 0.5$ & $10.0 \pm 0.8$ & $6.96 \pm 0.21$ & $15.2 \pm 0.6$ \\
Positive control & $51.6 \pm 0.1$ & $4.7 \pm 0.2$ & $3.48 \pm 0.26$ & $5.67 \pm 0.02$ \\
& & $57.9 \pm 3.2^{b)}$ & $46.96 \pm 1.86^{b)}$ & $77.9 \pm 2.3^{b)}$ \\
\hline
\end{tabular}

a) Percent growth inhibition of $60 \mu \mathrm{M}$ resveratrol in DLD-1 cell. b) Percent growth inhibition of $0.03 \mu \mathrm{M}$ campothecin in HeLa, MCF-7 and NCI-H460 cells.

$\mathrm{IC}_{50}$ values (data not shown). Of the isolated compounds, 4 showed the strongest inhibitory effect with $\mathrm{IC}_{50}$ values of 1.6, $4.7,3.5$ and $5.7 \mu \mathrm{M}$, respectively, against the four cancer cell lines. The replacement of a prenyl group at C- 6 as in 4 by a geranyl side chain as in $\mathbf{1}$ resulted in a significant decrease of the activity against the NCI-H460 cells $\left(\mathrm{IC}_{50} 23.8 \mu \mathrm{M}\right)$. However, compound $\mathbf{2}$ with a geranyl group exhibited much stronger inhibitory effect compared with $\mathbf{3}$ which possessed a prenyl group. Although the latter result was consistent with previous results by Laphookhieo et al. ${ }^{9)}$ in which effect of 2 and 3 against the cell number of MCF-7, HeLa, KB and HT29 cell lines were tested. The above results therefore could not readily be explained in terms of substituted coumarin structures.

Cell cycle analysis of DLD-1 performed on the four coumarins $(\mathbf{1}-\mathbf{4})$ at their $\mathrm{IC}_{50}$ concentration showed that all the compounds increased the $\mathrm{G}_{0} / \mathrm{G}_{1}$ fraction whereas 2 achieved sub- $\mathrm{G}_{1}$ apoptotic cells more significantly after $48 \mathrm{~h}$ (nearly 60\%) compared to those of $\mathbf{1 , 3}$ and $\mathbf{4}$ (Fig. 4), which may indicate that $\mathbf{2}$ could influence cell number by a different cellular mechanism, likely by apoptosis.

Comparison of the effect of the nine methylated derivatives $(\mathbf{1} \mathbf{a}-\mathbf{1} \mathbf{c}, \mathbf{2} \mathbf{a}-\mathbf{2} \mathbf{b}, \mathbf{3} \mathbf{a}-\mathbf{3 b}$ and $\mathbf{4 a}-\mathbf{4 c})$ and their parental compounds $(\mathbf{1}-\mathbf{4})$ on cell number was also carried out using SRB assay. DLD-1 cells were exposed at the concentration $20 \mu \mathrm{M}$ of each of the nine derivatives and $4 \mu \mathrm{M}$ of each of the four natural occurring compounds and incubator for $48 \mathrm{~h}$. The result is summarized in Table 3. The parent compounds with three hydroxyls showed strongest inhibitory activity $(\mathrm{ca} .70 \%)$ at $4 \mu \mathrm{M}$ substance. Among the derivates 1a, 2a, 3a and 4a with one free hydroxyl exhibited the lowest inhibitory effect (ca. 10\%) whereas $\mathbf{1 b}, \mathbf{2 b}, \mathbf{3 b}$ and $\mathbf{4 b}$ showed highest inhibitory activity and $\mathbf{1 c}$ and $\mathbf{4 c}$ intermediate activity. Inhibition of cell proliferation efficacy against DLD1 cells thus correlated with the number of hydroxyl groups in coumarins. Coumarins with more hydroxyl groups exhibited stronger inhibition. In addition, the replacement of the hydroxyl groups by the methoxyl groups seemed to attenuate antiproliferative potency and the presence of phenolic groups seemed to play a more important role than that of alcoholic groups in enhancing the inhibitory effect on cell number.

\section{Experimental}

General Experimental Procedures Thin layer chromatography (TLC) was performed using precoated glass TLC plates normal phase (Merck, $250 \mu \mathrm{m}$ ) and $\mathrm{RP}_{18}$ (Merck, $200 \mu \mathrm{m}$ ). TLC plates were visualized using UV light, staining with $\mathrm{I}_{2}$ or spraying with methanolic $\mathrm{FeCl}_{3}$ for detection of phenolic compounds. Column chromatography (CC) was carried out on silica gel (Merck, $40-63 \mu \mathrm{m}$ ) or $\mathrm{RP}_{18}$ (Merck, 40-63 $\mu \mathrm{m}$ ) bonded phases.

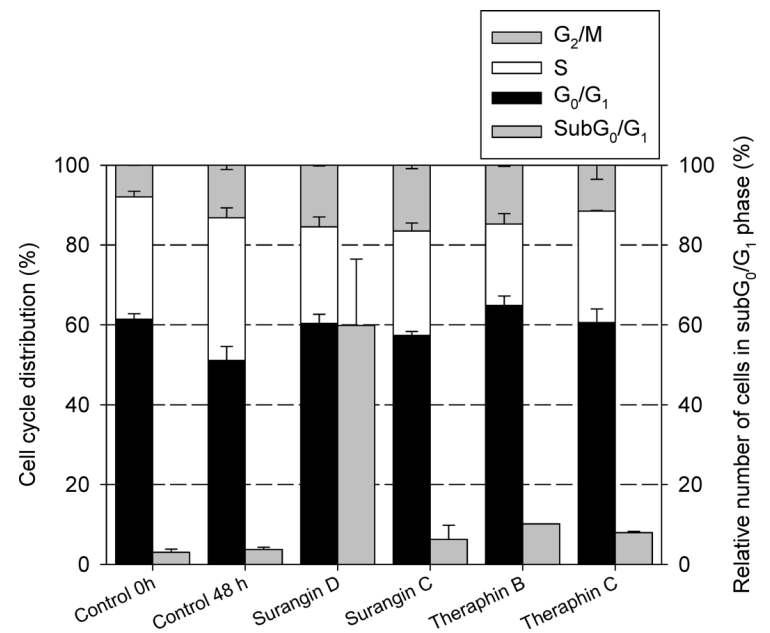

Fig. 4. Effect of $\mathbf{1}-\mathbf{4}$ on Cell Cycle Distribution and $\operatorname{subG}_{0} / \mathrm{G}_{1}$ Cell Fraction

DLD-1 cells were exposed to $\mathbf{1}-\mathbf{4}$ at their $\mathrm{IC}_{50}$ levels for $48 \mathrm{~h}$. The fraction of cells in the various cell phases and the level of cells in $\operatorname{subG}_{0} / \mathrm{G}_{1}$ were determined by FACS analysis. Figure showed means and range of one experiment with two determinations.

Table 3. Cell Number Inhibitory Effects ${ }^{a}$ of Methylated Derivatives (1a4c) Compared with the Parental Compounds $(\mathbf{1}-\mathbf{4})$

\begin{tabular}{crcc}
\hline \hline Compound $^{b)}$ & GI (\%) & Compound & GI (\%) \\
\hline $\mathbf{1}$ & $68.1 \pm 0.8^{c)}$ & $\mathbf{3}$ & $69.2 \pm 0.7$ \\
$\mathbf{1 a}$ & $7.7 \pm 1.9$ & $\mathbf{3 a}$ & $10.3 \pm 3.7$ \\
$\mathbf{1 b}$ & $70.5 \pm 1.7$ & $\mathbf{3 b}$ & $69.7 \pm 2.6$ \\
$\mathbf{1 c}$ & $40.1 \pm 3.7$ & $\mathbf{4}$ & $69.2 \pm 2.7$ \\
$\mathbf{2}$ & $67.6 \pm 5.7$ & $\mathbf{4 a}$ & $10.1 \pm 6.0$ \\
$\mathbf{2 a}$ & $10.5 \pm 0.7$ & $\mathbf{4 b}$ & $70.3 \pm 0.8$ \\
$\mathbf{2 b}$ & $72.6 \pm 4.1$ & $\mathbf{4 c}$ & $54.4 \pm 7.1$ \\
\hline
\end{tabular}

GI: growth inhibition of the tested compounds after $48 \mathrm{~h}$ of treatment. a) The inhibition of cell proliferation was estimated in DLD-1 cells using the SRB assay. $b$ ) The cells were exposed to the tested compounds $(4 \mu \mathrm{M}$ of $\mathbf{1}-\mathbf{4}$ or $20 \mu \mathrm{M}$ of $\mathbf{1 a}-\mathbf{4 c})$ for $48 \mathrm{~h} . \quad c)$ The data presented are means of three experiments \pm S.D.

For gel permeation chromatography (GPC), Sephadex LH-20 (GE Healthcare) with $\mathrm{CHCl}_{3}-\mathrm{MeOH} 1: 1$ as eluent was used.

Optical rotations were performed on an A. Krüss Optronic polarimeter. UV spectra were measured using an Agilent 8453 spectrophotometer or a Synergy HT-Bio-Tek microplate ELISA plate reader (for SRB assay). IR spectra were recorded in $\mathrm{KBr}$ using a Bruker Tensor 37 spectrophotometer. HR-ESI-MS was performed on a Bruker micrOTOF-QII $(80 \mathrm{eV})$ mass spectrometer. NMR spectra were measured using a Bruker AV $500[500 \mathrm{MHz}$ $\left({ }^{1} \mathrm{H}\right)$ and $\left.125 \mathrm{MHz}\left({ }^{13} \mathrm{C}\right)\right]$, a Varian Mercury $\left[300 \mathrm{MHz}\left({ }^{1} \mathrm{H}\right)\right.$ and $75 \mathrm{MHz}$ $\left.\left({ }^{13} \mathrm{C}\right)\right]$ or a Bruker AC $200\left[200 \mathrm{MHz}\left({ }^{1} \mathrm{H}\right)\right.$ and $\left.50 \mathrm{MHz}\left({ }^{13} \mathrm{C}\right)\right]$ with TMS as an internal standard and $\mathrm{CDCl}_{3}$ as the solvent. Multiplicities were determined using the distortionless enhancement by polarization transfer (DEPT) pulse sequence.

Cytotoxic activity was set up in Nunclon $^{\mathrm{TM}}$ surface 96 wells $\left(\mathrm{Nunc}^{\mathrm{TM}}\right.$ ). McCoy's 5A medium, saline, trypsin, Versene, gentamicin were obtained from GIBCO. Fetal bovine serum (FBS) was obtained from SERO-Med. Resveratrol, dimethyl sulfoxide, sulforhodamine B (SRB), trichloroacetic acid, RNAse and propidium iodide were purchased from Sigma-Aldrich. Tris-base and acetic acid were from Merck.

Plant Material The bark of Mammea siamensis was collected from Ma Da Plantation, south Vietnam and identified by Mr. Nguyen Thien Tich, Department of Botany and Ecology, Ho Chi Minh City University of Science. A voucher specimen (trautrau-11) was deposited at Natural Product and Medicinal Chemistry Lab, Faculty of Chemistry, Ho Chi Minh City University of Science.

Extraction and Isolation The dried and ground bark $(2 \mathrm{~kg})$ was extracted with petroleum ether and ethyl acetate, respectively, using a Soxhlet extractor. Concentration of the solvents gave a petroleum ether extract $(\mathrm{OSH})$ and an EtOAc extract (OSE). 
The petroleum ether extract $(\mathrm{OSH}, 89 \mathrm{~g})$ was fractionated over a column of silica gel with an EtOAc-petroleum ether gradient to give ten frs. (OSH1-OSH10). Fr. OSH2 (2.16 g) was separated by CC (silica gel, acetone-petroleum ether) and followed by GPC to yield surangin B $(\mathbf{5}, 57 \mathrm{mg})$. Fr. 5 (OSH5, $10 \mathrm{~g}$ ) was separated using CC (silica gel, $0-50 \%$ acetone-petroleum ether) to give 3 frs. (OSH5.1-5.3). Fr. OSH5.1 was purified by GPC to give 1,7-dihydroxyxanthone $(6)(20 \mathrm{mg})$. CC of fr OSH5.2 (4.0 g) on $\mathrm{RP}_{18}\left(70-90 \% \mathrm{MeOH}-\mathrm{H}_{2} \mathrm{O}\right)$ afforded 3 frs. (OSH5.2.1-5.2.3). The first fr was purified using $\mathrm{CC}$ (silica gel, $2 \% \mathrm{EtOAc}-\mathrm{CHCl}_{3}$ ) and then GPC to furnish theraphin B (3,120 mg) and theraphin C (4,105 mg). Similarly, the second fr was subjected to $\mathrm{CC}$ (silica gel, $2 \%$ EtOAc- $\mathrm{CHCl}_{3}$ ) and then GPC to give surangin $\mathrm{C}(\mathbf{2}, 120 \mathrm{mg})$ and surangin $\mathrm{D}(\mathbf{1}, 135 \mathrm{mg})$. Fr. OSH8 was separated by $\mathrm{CC}$ (silica gel, EtOAc-petroleum ether) to give four frs. (OSH8.1-8.4). Fr. OSH8.3 (200 mg) was fractionated using CC (silica gel, $0-100 \%$ EtOAc-petroleum ether) and then purified by GPC to furnish 7 hydroxy-1-methoxyxanthone $(\mathbf{1 0}, 11 \mathrm{mg})$, 1,7-dimethoxyxanthone (11, $16 \mathrm{mg}$ ) and 1,7-dimethoxy-6-hydroxyxanthone (12,8 $\mathrm{mg})$.

Treatment of $\mathbf{1}-\mathbf{4}$ (100 mg of each) with $\mathrm{CH}_{3} \mathrm{I}$ and $\mathrm{K}_{2} \mathrm{CO}_{3}$ in acetone in $24 \mathrm{~h}$ at room temperature and then purification using $\mathrm{CC}$ (silica gel, $0-30 \%$ EtOAc-petroleum ether) furnished 1a $(18.6 \mathrm{mg}), \mathbf{1 b}(16.3 \mathrm{mg}), \mathbf{1 c}(14.0 \mathrm{mg})$, 1d $(20 \mathrm{mg}), \mathbf{2 a}(24.6 \mathrm{mg}), \mathbf{2 b}(13.4 \mathrm{mg}), \mathbf{3 a}(7.0 \mathrm{mg}), \mathbf{3 b}(9.0 \mathrm{mg}), \mathbf{4 a}$ $(10.0 \mathrm{mg}), \mathbf{4 b}(8.5 \mathrm{mg})$ and $\mathbf{4 c}(9.0 \mathrm{mg})$

The EtOAc extract was subjected to $\mathrm{CC}$ (silica gel, EtOAc-petroleum ether) to give nine frs (OSE1-9). Fr. OSE3 (460 mg) was separated using CC (silica gel, 0-25\% EtOAc-petroleum ether) and then $\mathrm{RP}_{18}\left(\mathrm{MeOH}-\mathrm{H}_{2} \mathrm{O}\right)$ and finally GPC to yield 1,6,7-trihydroxyxanthone $(7,12.0 \mathrm{mg}), 1,3,7$-trihydroxyxanthone $(\mathbf{8}, 6.0 \mathrm{mg})$ and 1,7-dihydroxy-3-methoxyxanthone $(\mathbf{9}$, $5.0 \mathrm{mg})$.

Surangin D (1): Yellowish gum; UV $\lambda_{\max }(\mathrm{EtOH}) \mathrm{nm}: 225,300$ and $325 \mathrm{~nm}$; IR $v_{\max }(\mathrm{KBr}) \mathrm{cm}^{-1}: 2963,2932,2877,1739,1708,1580,1111$ $873 ;[\alpha]_{\mathrm{D}}^{27}-119.3(c=0.69, \mathrm{MeOH}) ;{ }^{1} \mathrm{H}-$ and ${ }^{13} \mathrm{C}-\mathrm{NMR}$ : see Table 1 ; HMBC: see Table 1 and Fig. 3; HR-ESI-MS $m / z$ : $457.2585[\mathrm{M}+\mathrm{H}]^{+}(\mathrm{Calcd}$ for $\mathrm{C}_{27} \mathrm{H}_{36} \mathrm{O}_{6}, 457.2580$ ).

5,9-Di-O-methyl Surangin D (1a): Yellowish gum; ${ }^{1} \mathrm{H}-\mathrm{NMR}(300 \mathrm{MHz}$, $\left.\mathrm{CDCl}_{3}\right) \delta: 14.33(1 \mathrm{H}, \mathrm{s}, 7-\mathrm{OH}), 6.56(1 \mathrm{H}, \mathrm{d}, J=0.8 \mathrm{~Hz}, \mathrm{H}-3), 5.23(1 \mathrm{H}, \mathrm{t}$, $J=7.1 \mathrm{~Hz}, \mathrm{H}-13), 5.04(1 \mathrm{H}, \mathrm{t}, J=6.9 \mathrm{~Hz}, \mathrm{H}-17), 4.70(1 \mathrm{H}$, ddd, $J=7.8,2.4$, $0.8 \mathrm{~Hz}, \mathrm{H}-9), 3.80$ and 3.40 (3H each, s, 5-OMe, 9-OMe), 3.46 and 3.35 $\left(1 \mathrm{H}, \mathrm{dd}, J=15.0,7.1 \mathrm{~Hz}, \mathrm{H}_{2}-12\right), 3.20\left(2 \mathrm{H}, \mathrm{d}, J=6.6 \mathrm{~Hz}, \mathrm{H}_{2}-23\right), 2.31(1 \mathrm{H}$, nont, $J=6.6 \mathrm{~Hz}, \mathrm{H}-24), 2.08$ and 2.00 ( $2 \mathrm{H}$ each, $\left.\mathrm{m}, \mathrm{H}_{2}-16, \mathrm{H}_{2}-15\right), 1.92$ and 1.77 ( $1 \mathrm{H}$ each, $\left.\mathrm{m}, \mathrm{H}_{2}-10\right), 1.77,1.63$ and 1.57 ( $3 \mathrm{H}$ each, s, $\mathrm{H}_{3}-20, \mathrm{H}_{3}-21, \mathrm{H}_{3}$ 19), $1.05\left(6 \mathrm{H}, \mathrm{d}, J=6.6 \mathrm{~Hz}, \mathrm{H}_{3}-25, \mathrm{H}_{3}-26\right)$ and $1.02\left(3 \mathrm{H}, \mathrm{t}, J=7.2 \mathrm{~Hz}, \mathrm{H}_{3}\right.$ $11) ;{ }^{13} \mathrm{C}-\mathrm{NMR}\left(75 \mathrm{MHz} \mathrm{CDCl}_{3}\right) \delta: 206.7,166.7,160.8,159.7,157.8,155.5$, 136.4 and 131.4 (C, C-22, C-7, C-2, C-5, C-4, C-8a, C-14, C-18), 124.3, 121.2 and 107.8 (CH, C-17, C-13, C-3), 120.9, 107.2 and 105.0 (C, C-6, C8, C-4a), 81.9 ( CH, C-9), 62.6 and 57.9 $\left(\mathrm{CH}_{3}, 5-\mathrm{OMe}, 9-\mathrm{OMe}\right), 53.9,39.6$, 30.3 and $26.5\left(\mathrm{CH}_{2}, \mathrm{C}-23, \mathrm{C}-15, \mathrm{C}-10, \mathrm{C}-16\right), 25.7\left(\mathrm{CH}_{3}, \mathrm{C}-21\right), 25.5(\mathrm{CH}$, C-24), $23.0\left(\mathrm{CH}_{2}, \mathrm{C}-12\right), 22.7\left(\mathrm{CH}_{3}, \mathrm{C}-26, \mathrm{C}-25\right), 17.7,16.3$ and $10.5\left(\mathrm{CH}_{3}\right.$, C-19, C-20, C-11); HR-ESI-MS $m / z$ : $485.2898\left[^{\mathrm{M}+\mathrm{H}]^{+}}\right.$(Calcd for $\left.\mathrm{C}_{29} \mathrm{H}_{40} \mathrm{O}_{6}, 485.2892\right)$.

9-O-Methyl Surangin D (1b): Yellowish gum; ${ }^{1} \mathrm{H}-\mathrm{NMR}(300 \mathrm{MHz}$, $\left.\mathrm{CDCl}_{3}\right) \delta: 14.40(1 \mathrm{H}, \mathrm{s}, 7-\mathrm{OH}), 6.15(1 \mathrm{H}, \mathrm{s}, \mathrm{H}-3), 5.21(1 \mathrm{H}, \mathrm{t}, J=6.0 \mathrm{~Hz}, \mathrm{H}-$ 13), $5.07(1 \mathrm{H}, \mathrm{t}, J=5.4 \mathrm{~Hz}, \mathrm{H}-17), 4.16(1 \mathrm{H}, \mathrm{t}, J=7.2 \mathrm{~Hz}, \mathrm{H}-9), 3.52(3 \mathrm{H}, \mathrm{s}$, 9-OMe), 3.41 ( $\left.2 \mathrm{H}, \mathrm{m}, \mathrm{H}_{2}-12\right), 3.13\left(2 \mathrm{H}\right.$, dd, $\left.J=6.7,2.4 \mathrm{~Hz}, \mathrm{H}_{2}-23\right), 2.28$ ( $1 \mathrm{H}$, nont, $J=6.7 \mathrm{~Hz}, \mathrm{H}-24), 2.06$ and 2.02 (2H each, $\left.\mathrm{m}, \mathrm{H}_{2}-16, \mathrm{H}_{2}-15\right), 1.98$ ( $\left.2 \mathrm{H}, \mathrm{m}, \mathrm{H}_{2}-10\right), 1.80,1.64$ and 1.57 (3H each, s, $\left.\mathrm{H}_{3}-20, \mathrm{H}_{3}-21, \mathrm{H}_{3}-19\right), 1.03$ $\left(6 \mathrm{H}, \mathrm{d}, J=6.7 \mathrm{~Hz}, \mathrm{H}_{3}-25, \mathrm{H}_{3}-26\right)$ and $1.02\left(3 \mathrm{H}, \mathrm{t}, J=7.2 \mathrm{~Hz}, \mathrm{H}_{3}-11\right) ;{ }^{13} \mathrm{C}-$ NMR $\left(75 \mathrm{MHz}, \mathrm{CDCl}_{3}\right) \delta: 205.9,166.5,158.6,157.8,156.7,153.2,136.4$ and $131.3(\mathrm{C}, \mathrm{C}-22, \mathrm{C}-7, \mathrm{C}-2, \mathrm{C}-5, \mathrm{C}-4, \mathrm{C}-8 \mathrm{a}, \mathrm{C}-14, \mathrm{C}-18), 124.3,121.4$ and 111.2 (CH, C-17, C-13, C-3), 114.0, 104.5 and 100.2 (C, C-6, C-8, C-4a), $88.3(\mathrm{CH}, \mathrm{C}-9), 57.8\left(\mathrm{CH}_{3}, 9-\mathrm{OMe}\right), 53.8,39.8,27.2$ and $26.7\left(\mathrm{CH}_{2}, \mathrm{C}-23\right.$, $\mathrm{C}-15, \mathrm{C}-10, \mathrm{C}-16), 25.7\left(\mathrm{CH}_{3}, \mathrm{C}-21\right), 25.5(\mathrm{CH}, \mathrm{C}-24), 22.7\left(\mathrm{CH}_{3}, \mathrm{C}-26, \mathrm{C}-\right.$ 25), $22.0\left(\mathrm{CH}_{2}, \mathrm{C}-12\right), 17.7,16.3$ and $10.5\left(\mathrm{CH}_{3}, \mathrm{C}-19, \mathrm{C}-20, \mathrm{C}-11\right)$; HRESI-MS $m / z$ : $471.2741[\mathrm{M}+\mathrm{H}]^{+}\left(\right.$Calcd for $\left.\mathrm{C}_{28} \mathrm{H}_{38} \mathrm{O}_{6}, 471.2736\right)$.

5-O-Methyl Surangin D (1c): Yellowish gum; ${ }^{1} \mathrm{H}-\mathrm{NMR}(300 \mathrm{MHz}$, $\left.\mathrm{CDCl}_{3}\right) \delta: 14.31(1 \mathrm{H}, \mathrm{s}, 7-\mathrm{OH}), 6.68(1 \mathrm{H}, \mathrm{d}, J=1.2 \mathrm{~Hz}, \mathrm{H}-3), 5.21(2 \mathrm{H}, \mathrm{m}$, H-13, H-9), 5.04 (1H, t, J=5.4 Hz, H-17), 3.79 (3H, s, 5-OMe), $3.45(1 \mathrm{H}$, $\mathrm{dd}, J=15.0,6.9 \mathrm{~Hz})$ and $3.34(1 \mathrm{H}, \mathrm{dd}, J=15.0,5.7 \mathrm{~Hz}) \mathrm{H}_{2}-12,3.19(2 \mathrm{H}, \mathrm{d}$, $\left.J=6.5 \mathrm{~Hz}, \mathrm{H}_{2}-23\right), 2.28$ (1H, nont, $\left.J=6.5 \mathrm{~Hz}, \mathrm{H}-24\right), 2.06$ and 2.01 ( $2 \mathrm{H}$ each, $\left.\mathrm{m}, \mathrm{H}_{2}-16, \mathrm{H}_{2}-15\right), 1.88\left(2 \mathrm{H}, \mathrm{qd}, J=7.5,3.0 \mathrm{~Hz}, \mathrm{H}_{2}-10\right), 1.77,1.63$ and 1.57 ( $3 \mathrm{H}$ each, s, $\left.\mathrm{H}_{3}-20, \mathrm{H}_{3}-21, \mathrm{H}_{3}-19\right), 1.08\left(3 \mathrm{H}, \mathrm{t}, J=7.8 \mathrm{~Hz}, \mathrm{H}_{3}-11\right)$ and 1.04 $\left(6 \mathrm{H}, \mathrm{d}, J=6.5 \mathrm{~Hz}, \mathrm{H}_{3}-25, \mathrm{H}_{3}-26\right) ;{ }^{13} \mathrm{C}-\mathrm{NMR}\left(75 \mathrm{MHz}, \mathrm{CDCl}_{3}\right) \delta: 206.7$, 166.7, 160.6, 159.7, 159.6, 155.2, 136.4 and 131.4 (C, C-22, C-7, C-2, C-5, C-4, C-8a, C-14, C-18), 124.1, 121.7 and 108.0 (CH, C-17, C-13, C-3), 121.2, 107.2 and 104.5 (C, C-6, C-8, C-4a), 71.8 (CH, C-9), $62.9\left(\mathrm{CH}_{3}, 5-\right.$
OMe $), 53.9,39.6,31.1$ and $26.5\left(\mathrm{CH}_{2}, \mathrm{C}-23, \mathrm{C}-15, \mathrm{C}-10, \mathrm{C}-16\right), 25.7\left(\mathrm{CH}_{3}\right.$, C-21), 25.4 (CH, C-24), $22.9\left(\mathrm{CH}_{2}, \mathrm{C}-12\right), 22.7\left(\mathrm{CH}_{3}, \mathrm{C}-26, \mathrm{C}-25\right), 17.7$ 16.3 and $10.6\left(\mathrm{CH}_{3}, \mathrm{C}-19, \mathrm{C}-20, \mathrm{C}-11\right)$; HR-ESI-MS $m / z: 471.2741$ $[\mathrm{M}+\mathrm{H}]^{+}\left(\right.$Calcd for $\left.\mathrm{C}_{28} \mathrm{H}_{38} \mathrm{O}_{6}, 471.2736\right)$

5,7,9-Tri- $O$-methyl Surangin D (1d): Yellowish gum; ${ }^{1} \mathrm{H}-\mathrm{NMR}(200 \mathrm{MHz}$, $\left.\mathrm{CDCl}_{3}\right) \delta: 6.58(1 \mathrm{H}, \mathrm{d}, J=0.9 \mathrm{~Hz}, \mathrm{H}-3), 5.15(1 \mathrm{H}, \mathrm{t}, J=6.5 \mathrm{~Hz}, \mathrm{H}-13), 5.04$ $(1 \mathrm{H}, \mathrm{t}, J=6.7 \mathrm{~Hz}, \mathrm{H}-17), 4.69(1 \mathrm{H}, \mathrm{dd}, J=6.0,2.1 \mathrm{~Hz}, \mathrm{H}-9), 3.78,3.76$ and 3.39 (3H each, s, 5-OMe, 7-OMe, 9-OMe), 3.46 and 3.31 (1H each, dd, $\left.J=15.3,6.5 \mathrm{~Hz}, \mathrm{H}_{2}-12\right), 2.78\left(2 \mathrm{H}, \mathrm{dd}, J=6.8,1.6 \mathrm{~Hz}, \mathrm{H}_{2}-23\right), 2.32$ (1H, sept, $J=6.8 \mathrm{~Hz}, \mathrm{H}-24), 2.05$ and $2.00\left(2 \mathrm{H}\right.$ each, $\left.\mathrm{m}, \mathrm{H}_{2}-16, \mathrm{H}_{2}-15\right), 1.79$ and 1.42 (1H each, $\left.\mathrm{m}, \mathrm{H}_{2}-10\right), 1.76,1.63$ and 1.57 (3H each, $\left.\mathrm{s}, \mathrm{H}_{3}-20, \mathrm{H}_{3}-21, \mathrm{H}_{3}-19\right)$, $1.02\left(6 \mathrm{H}, \mathrm{d}, J=6.8 \mathrm{~Hz}, \mathrm{H}_{3}-25, \mathrm{H}_{3}-26\right)$ and $1.04\left(3 \mathrm{H}, \mathrm{t}, J=7.4 \mathrm{~Hz}, \mathrm{H}_{3}-11\right)$; ${ }^{13} \mathrm{C}-\mathrm{NMR}\left(50 \mathrm{MHz} \mathrm{CDCl}_{3}\right) \delta: 202.1,159.8,158.4,156.9,156.4,150.3$, 136.3 and 131.5 (C, C-22, C-2, C-5, C-7, C-4, C-8a, C-14, C-18), 124.0, 122.4 and 110.7 (CH, C-17, C-13, C-3), 126.3, 122.4 and 109.5 (C, C-6, C8, C-4a), 81.5 (CH, C-9), 63.3, 62.7 and 57.8 $\left(\mathrm{CH}_{3}, 5-\mathrm{OMe}, 7-\mathrm{OMe}\right.$, 9$\mathrm{OMe}), 54.0,39.5,30.1$ and $26.4\left(\mathrm{CH}_{2}, \mathrm{C}-23, \mathrm{C}-15, \mathrm{C}-10, \mathrm{C}-16\right), 25.6\left(\mathrm{CH}_{3}\right.$, $\mathrm{C}-21), 24.0(\mathrm{CH}, \mathrm{C}-24), 23.2\left(\mathrm{CH}_{2}, \mathrm{C}-12\right), 22.5\left(\mathrm{CH}_{3}, \mathrm{C}-26, \mathrm{C}-25\right), 17.6$ 16.2 and $10.4\left(\mathrm{CH}_{3}, \mathrm{C}-19, \mathrm{C}-20, \mathrm{C}-11\right)$; HR-ESI-MS $\mathrm{m} / \mathrm{z}: 498.2978$ [M] $^{+}$ (Calcd for $\mathrm{C}_{30} \mathrm{H}_{42} \mathrm{O}_{6}, 498.2970$ )

5,9-Di-O-methyl Surangin C (2a): Yellowish gum; ${ }^{1} \mathrm{H}-\mathrm{NMR}(300 \mathrm{MHz}$, $\left.\mathrm{CDCl}_{3}\right) \delta: 14.22(1 \mathrm{H}, \mathrm{s}, 7-\mathrm{OH}), 6.56(1 \mathrm{H}, \mathrm{d}, J=0.5 \mathrm{~Hz}, \mathrm{H}-3), 5.21(1 \mathrm{H}, \mathrm{t}$, $J=6.8 \mathrm{~Hz}, \mathrm{H}-13), 5.04(1 \mathrm{H}, \mathrm{t}, J=6.5 \mathrm{~Hz}, \mathrm{H}-17), 4.72(1 \mathrm{H}, \mathrm{dd}, J=8.0,2.5 \mathrm{~Hz}$, H-9), 3.94 (1H, sext, $J=6.5 \mathrm{~Hz}, \mathrm{H}-23$ ), 3.80 and 3.40 (3H each, s, 5-OMe, 9$\mathrm{OMe}$ ), 3.45 and 3.34 ( $1 \mathrm{H}$ each, dd, $\left.J=15.0,7.0 \mathrm{~Hz}, \mathrm{H}_{2}-12\right), 2.06(2 \mathrm{H}, \mathrm{t}$, $\left.J=6.0 \mathrm{~Hz}, \mathrm{H}_{2}-16\right), 2.01\left(2 \mathrm{H}, \mathrm{t}, J=6.0 \mathrm{~Hz}, \mathrm{H}_{2}-15\right), 1.92$ and $1.78(1 \mathrm{H}$ each, $\left.\mathrm{m}, \mathrm{H}_{2}-10\right), 1.77,1.63$ and 1.57 (3H each, s, $\left.\mathrm{H}_{3}-20, \mathrm{H}_{3}-21, \mathrm{H}_{3}-19\right), 1.43(2 \mathrm{H}$, $\left.\mathrm{m}, \mathrm{H}_{2}-24\right), 1.27\left(3 \mathrm{H}, \mathrm{d}, J=6.8 \mathrm{~Hz}, \mathrm{H}_{3}-26\right), 1.03\left(3 \mathrm{H}, \mathrm{t}, J=7.5 \mathrm{~Hz}, \mathrm{H}_{3}-11\right)$ and $1.00\left(3 \mathrm{H}, \mathrm{t}, J=7.5 \mathrm{~Hz}, \mathrm{H}_{3}-25\right) ;{ }^{13} \mathrm{C}-\mathrm{NMR}\left(75 \mathrm{MHz} \mathrm{CDCl}_{3}\right) \delta: 211.3,166.8$, $160.8,159.7,158.0,155.3,136.4$ and 131.4 (C, C-22, C-7, C-2, C-5, C-4, C8a, C-14, C-18), 124.2, 121.9 and 107.8 (CH, C-17, C-13, C-3), 121.0, 106.9 and 105.1 (C, C-6, C-8, C-4a), 82.0 and 47.3 (CH, C-9, C-23), 62.5 and $57.9\left(\mathrm{CH}_{3}, 5-\mathrm{OMe}, 9-\mathrm{OMe}\right), 39.6,30.4,27.1$ and $26.6\left(\mathrm{CH}_{2}, \mathrm{C}-15, \mathrm{C}-\right.$ $10, \mathrm{C}-24, \mathrm{C}-16), 25.6\left(\mathrm{CH}_{3}, \mathrm{C}-21\right), 23.0\left(\mathrm{CH}_{2}, \mathrm{C}-12\right), 17.6,16.6,16.3,11.7$ and $10.5\left(\mathrm{CH}_{3}, \mathrm{C}-19, \mathrm{C}-26, \mathrm{C}-20, \mathrm{C}-25, \mathrm{C}-11\right)$; HR-ESI-MS $m / z: 485.2898$ $[\mathrm{M}+\mathrm{H}]^{+}\left(\right.$Calcd for $\left.\mathrm{C}_{29} \mathrm{H}_{40} \mathrm{O}_{6}, 485.2892\right)$.

9-O-Methyl Surangin C (2b): Yellowish gum; ${ }^{1} \mathrm{H}-\mathrm{NMR}(300 \mathrm{MHz}$, $\left.\mathrm{CDCl}_{3}\right) \delta: 14.29(1 \mathrm{H}, \mathrm{s}, 7-\mathrm{OH}), 6.16(1 \mathrm{H}, \mathrm{s}, \mathrm{H}-3), 5.22(1 \mathrm{H}, \mathrm{t}, J=6.9 \mathrm{~Hz}, \mathrm{H}-$ 13), $5.07(1 \mathrm{H}, \mathrm{t}, J=6.6 \mathrm{~Hz}, \mathrm{H}-17), 4.17(1 \mathrm{H}, \mathrm{t}, J=7.2 \mathrm{~Hz}, \mathrm{H}-9), 3.87(1 \mathrm{H}$, sext, $J=6.6 \mathrm{~Hz}, \mathrm{H}-23), 3.53(3 \mathrm{H}, \mathrm{s}, 9-\mathrm{OMe}), 3.41\left(2 \mathrm{H}, \mathrm{m}, \mathrm{H}_{2}-12\right), 2.05$ and 2.00 (2H each, $\left.\mathrm{m}, \mathrm{H}_{2}-16, \mathrm{H}_{2}-15\right), 1.90\left(2 \mathrm{H}, \mathrm{m}, \mathrm{H}_{2}-10\right), 1.80,1.64$ and 1.57 ( $3 \mathrm{H}$ each, s, $\left.\mathrm{H}_{3}-20, \mathrm{H}_{3}-21, \mathrm{H}_{3}-19\right), 1.78$ and 1.47 (1H each, $\left.\mathrm{m}, \mathrm{H}_{2}-24\right), 1.26$ $\left(3 \mathrm{H}, \mathrm{d}, J=6.6 \mathrm{~Hz}, \mathrm{H}_{3}-26\right), 0.99$ and $0.98\left(3 \mathrm{H}\right.$ each, t, $J=7.5 \mathrm{~Hz}, \mathrm{H}_{3}-11, \mathrm{H}_{3}-$ $25) ;{ }^{13} \mathrm{C}-\mathrm{NMR}\left(\mathrm{CDCl}_{3}, 125 \mathrm{MHz}\right) \delta: 210.5,166.5,158.6,157.7,156.5$, 153.3, 136.4 and 131.3 (C, C-22, C-7, C-2, C-5, C-4, C-8a, C-14, C-18), 124.3, 121.4 and $111.2(\mathrm{CH}, \mathrm{C}-17, \mathrm{C}-13, \mathrm{C}-3), 114.1,104.2$ and $100.3(\mathrm{C}$, C-6, C-8, C-4a), 88.4 and 47.1 (CH, C-9, C-23), $57.9\left(\mathrm{CH}_{3}, 9-\mathrm{OMe}\right), 39.8$, 27.3, 27.2 and $26.7\left(\mathrm{CH}_{2}, \mathrm{C}-15, \mathrm{C}-10, \mathrm{C}-24, \mathrm{C}-16\right), 25.7\left(\mathrm{CH}_{3}, \mathrm{C}-21\right), 22.0$ $\left(\mathrm{CH}_{2}, \mathrm{C}-12\right), 17.7,16.7,16.3,11.8$ and $10.5\left(\mathrm{CH}_{3}, \mathrm{C}-19, \mathrm{C}-26, \mathrm{C}-20, \mathrm{C}-25\right.$, C-11); HR-ESI-MS $m / z$ : $471.2741[\mathrm{M}+\mathrm{H}]^{+}$(Calcd for $\mathrm{C}_{28} \mathrm{H}_{38} \mathrm{O}_{6}$, 471.2736).

5,9-Di-O-methyl Theraphin B (3a): Yellowish gum; ${ }^{1} \mathrm{H}-\mathrm{NMR}(300 \mathrm{MHz}$, $\left.\mathrm{CDCl}_{3}\right) \delta: 14.26(1 \mathrm{H}, \mathrm{s}, 7-\mathrm{OH}), 6.57(1 \mathrm{H}, \mathrm{s}, \mathrm{H}-3), 5.22(1 \mathrm{H}, \mathrm{t}$ sept, $J=7.0$, $1.3 \mathrm{~Hz}, \mathrm{H}-13), 4.71(1 \mathrm{H}, \mathrm{dd}, J=7.8,2.4 \mathrm{~Hz}, \mathrm{H}-9), 3.74(1 \mathrm{H}$, sext, $J=6.8 \mathrm{~Hz}$, H-18), 3.80 and 3.37 (3H each, s, 5-OMe, 9-OMe), 3.45 and 3.32 (1H each, dd, $\left.J=15.0,7.0 \mathrm{~Hz}, \mathrm{H}_{2}-12\right), 1.92$ and 1.80 (1 $\mathrm{H}$ each, $\left.\mathrm{m}, \mathrm{H}_{2}-10\right), 1.82$ and $1.71\left(3 \mathrm{H}\right.$ each, s, $\left.\mathrm{H}_{3}-16, \mathrm{H}_{3}-15\right), 1.46\left(2 \mathrm{H}, \mathrm{m}, \mathrm{H}_{2}-19\right), 1.27(3 \mathrm{H}, \mathrm{d}$, $\left.J=6.8 \mathrm{~Hz}, \mathrm{H}_{3}-21\right), 1.03\left(3 \mathrm{H}, \mathrm{t}, J=7.5 \mathrm{~Hz}, \mathrm{H}_{3}-11\right)$ and $1.00(3 \mathrm{H}, \mathrm{t}, J=7.5 \mathrm{~Hz}$, $\left.\mathrm{H}_{3}-20\right) ;{ }^{13} \mathrm{C}-\mathrm{NMR}\left(75 \mathrm{MHz}, \mathrm{CDCl}_{3}\right) \delta: 211.2,166.8,160.7,159.7,157.6$, 155.2 and 132.9 (C, C-17, C-7, C-2, C-5, C-4, C-8a, C-14), 121.7 and 107.8 (CH, C-13, C-3), 121.0, 106.8 and 105.1 (C, C-6, C-8, C-4a), 81.9 and 47.3 (CH, C-9, C-18), 62.6 and $57.9\left(\mathrm{CH}_{3}, 5-\mathrm{OMe}, 9-\mathrm{OMe}\right), 30.4$ and $27.1\left(\mathrm{CH}_{2}\right.$, C-10, C-19) $25.7\left(\mathrm{CH}_{3}, \mathrm{C}-16\right), 23.1\left(\mathrm{CH}_{2}, \mathrm{C}-12\right), 18.0,16.6,11.7$ and 10.6 $\left(\mathrm{CH}_{3}, \mathrm{C}-15, \mathrm{C}-21, \mathrm{C}-20, \mathrm{C}-11\right)$; HR-ESI-MS $m / z: 417.2272[\mathrm{M}+\mathrm{H}]^{+}(\mathrm{Calcd}$ for $\mathrm{C}_{24} \mathrm{H}_{32} \mathrm{O}_{6}, 417.2268$ ).

9-O-Methyl Theraphin B (3b): Yellowish gum; ${ }^{1} \mathrm{H}-\mathrm{NMR}(300 \mathrm{MHz}$, $\left.\mathrm{CDCl}_{3},\right) \delta: 14.29(1 \mathrm{H}, \mathrm{s}, 7-\mathrm{OH}), 6.15(1 \mathrm{H}, \mathrm{s}, \mathrm{H}-3), 5.23(1 \mathrm{H}, \mathrm{t}$ sept, $J=6.9$, $1.2 \mathrm{~Hz}, \mathrm{H}-13), 4.15$ (1H, t, $J=7.2 \mathrm{~Hz}, \mathrm{H}-9), 3.86$ (1H, sext, $J=6.8 \mathrm{~Hz}, \mathrm{H}-18$ ), $3.53(3 \mathrm{H}, \mathrm{s}, 9-\mathrm{OMe}), 3.41\left(2 \mathrm{H}, \mathrm{brd}, J=6.9 \mathrm{~Hz}, \mathrm{H}_{2}-12\right), 2.04(1 \mathrm{H}$, sept, $J=7.5 \mathrm{~Hz})$ and $\left.1.83(1 \mathrm{H}, \mathrm{m}) \mathrm{H}_{2}-10\right), 1.80$ and $1.70\left(3 \mathrm{H}\right.$ each, s, $\mathrm{H}_{3}-16, \mathrm{H}_{3}$ 15), 1.83 and 1.41 ( $1 \mathrm{H}$ each, $\left.\mathrm{m}, \mathrm{H}_{2}-19\right), 1.26\left(3 \mathrm{H}, \mathrm{d}, J=6.8 \mathrm{~Hz}, \mathrm{H}_{3}-21\right), 0.99$ $\left(3 \mathrm{H}, \mathrm{t}, J=7.5 \mathrm{~Hz}, \mathrm{H}_{3}-11\right)$ and $0.98\left(3 \mathrm{H}, \mathrm{t}, J=7.8 \mathrm{~Hz}, \mathrm{H}_{3}-20\right) ;{ }^{13} \mathrm{C}-\mathrm{NMR}$ $\left(75 \mathrm{MHz}, \mathrm{CDCl}_{3}\right) \delta: 210.5,166.5,158.7,157.7,156.6$ and $153.3(\mathrm{C}, \mathrm{C}-17$, C-7, C-2, C-5, C-4, C-8a), 132.9 (s, C-14), 121.5 and 111.2 (CH, C-13, C- 
3), 114.2, 104.3 and 100.2 (C, C-6, C-8, C-4a), 88.6 and 47.1 (CH, C-9, C18), $57.9\left(\mathrm{CH}_{3}, 9-\mathrm{OMe}\right), 27.3$ and $27.2\left(\mathrm{CH}_{2}, \mathrm{C}-10, \mathrm{C}-19\right) 25.8\left(\mathrm{CH}_{3}, \mathrm{C}-16\right)$, $22.1\left(\mathrm{CH}_{2}, \mathrm{C}-12\right), 17.9,16.7,11.8$ and $10.6\left(\mathrm{CH}_{3}, \mathrm{C}-15, \mathrm{C}-21, \mathrm{C}-20, \mathrm{C}-11\right)$; HR-ESI-MS $m / z$ : $403.2115[\mathrm{M}+\mathrm{H}]^{+}\left(\right.$Calcd for $\mathrm{C}_{23} \mathrm{H}_{30} \mathrm{O}_{6}, 403.2112$ ).

5,9-Di-O-methyl Theraphin C (4a): Yellowish gum; ${ }^{1} \mathrm{H}-\mathrm{NMR}(300 \mathrm{MHz}$, $\left.\mathrm{CDCl}_{3}\right) \delta: 14.33(1 \mathrm{H}, \mathrm{s}, 7-\mathrm{OH}), 6.56(1 \mathrm{H}, \mathrm{d}, J=0.9 \mathrm{~Hz}, \mathrm{H}-3), 5.22(1 \mathrm{H}, \mathrm{tq}$, $J=6.0,1.5 \mathrm{~Hz}, \mathrm{H}-13), 4.70$ (1H, ddd, $J=7.8,2.7,0.6 \mathrm{~Hz}, \mathrm{H}-9), 3.80$ and 3.40 (3H each, s, 5-OMe, 9-OMe), 3.45 and $3.38\left(1 \mathrm{H}, \mathrm{dd}, J=15.0,7.2 \mathrm{~Hz}, \mathrm{H}_{2}\right.$ 12), 3.19 ( $\left.2 \mathrm{H}, \mathrm{d}, J=6.7 \mathrm{~Hz}, \mathrm{H}_{2}-18\right), 2.30$ (1H, sept, $\left.J=6.7 \mathrm{~Hz}, \mathrm{H}-19\right), 1.98$ and $1.76(1 \mathrm{H}$ each, $\mathrm{m}) \mathrm{H}_{2}-10,1.78$ and 1.71 ( $3 \mathrm{H}$ each, $\left.\mathrm{s}, \mathrm{H}_{3}-16, \mathrm{H}_{3}-15\right), 1.04$ $\left(6 \mathrm{H}, \mathrm{d}, J=6.7 \mathrm{~Hz}, \mathrm{H}_{3}-20, \mathrm{H}_{3}-21\right), 1.03\left(3 \mathrm{H}, \mathrm{t}, J=7.5 \mathrm{~Hz}, \mathrm{H}_{3}-11\right) ;{ }^{13} \mathrm{C}-\mathrm{NMR}$ $\left(75 \mathrm{MHz}, \mathrm{CDCl}_{3}\right) \delta: 206.7,166.7,160.7,159.7,157.8,155.4$ and $132.9(\mathrm{C}$, C-17, C-7, C-2, C-5, C-4, C-8a, C-14), 121.7 and 107.8 (CH, C-13, C-3), 120.9, 107.2 and 105.0 (C, C-6, C-8, C-4a), 81.9 (CH, C-9), 62.7 and 57.9 $\left(\mathrm{CH}_{3}, 5-\mathrm{OMe}, 9-\mathrm{OMe}\right), 53.9$ and $30.3\left(\mathrm{CH}_{2}, \mathrm{C}-18, \mathrm{C}-10\right), 25.7\left(\mathrm{CH}_{3}, \mathrm{C}-15\right)$, $25.5(\mathrm{CH}, \mathrm{C}-19), 23.0\left(\mathrm{CH}_{2}, \mathrm{C}-12\right) 22.7\left(\mathrm{CH}_{3}, \mathrm{C}-20, \mathrm{C}-21\right), 17.0$ and 10.5 $\left(\mathrm{CH}_{3}, \mathrm{C}-16, \mathrm{C}-11\right)$; HR-ESI-MS $m / z: 417.2272[\mathrm{M}+\mathrm{H}]^{+}$(Calcd for $\left.\mathrm{C}_{24} \mathrm{H}_{32} \mathrm{O}_{6}, 417.2268\right)$.

9-O-Methyl Theraphin C (4b): Yellowish gum; ${ }^{1} \mathrm{H}-\mathrm{NMR}(300 \mathrm{MHz}$, $\left.\mathrm{CDCl}_{3}\right) \delta: 14.40(1 \mathrm{H}, \mathrm{s}, 7-\mathrm{OH}), 6.15(1 \mathrm{H}, \mathrm{s}, \mathrm{H}-3), 5.22(1 \mathrm{H}, \mathrm{t}$ sept, $J=6.9$, $1.2 \mathrm{~Hz}, \mathrm{H}-13), 4.14$ (1H, t, $J=7.2 \mathrm{~Hz}, \mathrm{H}-9), 3.52$ (3H, s, 9-OMe), $3.40(2 \mathrm{H}$, m, $\left.\mathrm{H}_{2}-12\right), 3.13\left(2 \mathrm{H}\right.$, dd, $\left.J=6.7,2.4 \mathrm{~Hz}, \mathrm{H}_{2}-18\right), 2.28(1 \mathrm{H}$, sept, $J=6.7 \mathrm{~Hz}$, $\mathrm{H}-19), 2.03$ and 1.81 (1H each, $\left.\mathrm{m}, \mathrm{H}_{2}-10\right), 1.80$ and 1.70 (3H each, s, $\mathrm{H}_{3}-16$, $\left.\mathrm{H}_{3}-15\right), 1.03\left(6 \mathrm{H}, \mathrm{d}, J=6.7 \mathrm{~Hz}, \mathrm{H}_{3}-20, \mathrm{H}_{3}-21\right), 0.99\left(3 \mathrm{H}, \mathrm{t}, J=7.5 \mathrm{~Hz}, \mathrm{H}_{3}\right.$ $11) ;{ }^{13} \mathrm{C}-\mathrm{NMR}\left(75 \mathrm{MHz}, \mathrm{CDCl}_{3}\right) \delta: 205.9,166.5,158.5,157.7,156.7,153.1$ and 132.8 (C, C-17, C-7, C-2, C-5, C-4, C-8a, C-14), 121.7 and $111.3(\mathrm{CH}$, C-13, C-3), 114.1, 104.5 and 100.2 (C, C-6, C-8, C-4a), 88.5 (CH, C-9), $57.8\left(\mathrm{CH}_{3}, 9-\mathrm{OMe}\right), 53.8$ and $27.2\left(\mathrm{CH}_{2}, \mathrm{C}-18, \mathrm{C}-10\right), 25.8\left(\mathrm{CH}_{3}, \mathrm{C}-15\right)$, $25.6(\mathrm{CH}, \mathrm{C}-19), 22.7\left(\mathrm{CH}_{3}, \mathrm{C}-20, \mathrm{C}-21\right), 22.1\left(\mathrm{CH}_{2}, \mathrm{C}-12\right), 17.9$ and 10.5

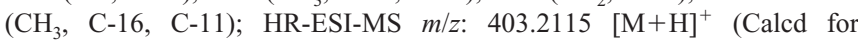
$\mathrm{C}_{23} \mathrm{H}_{30} \mathrm{O}_{6}, 403.2112$ ).

5-O-Methyl Theraphin C (4c): Yellowish gum; ${ }^{1} \mathrm{H}-\mathrm{NMR}(300 \mathrm{MHz}$, $\left.\mathrm{CDCl}_{3}\right) \delta: 14.32(1 \mathrm{H}, \mathrm{s}, 7-\mathrm{OH}), 6.67(1 \mathrm{H}, \mathrm{d}, J=0.9 \mathrm{~Hz}, \mathrm{H}-3), 5.20(2 \mathrm{H}, \mathrm{m}$, $\mathrm{H}-13, \mathrm{H}-9), 3.79$ ( $3 \mathrm{H}, \mathrm{s}, 5-\mathrm{OMe}), 3.44$ and 3.32 (1H each, dd, $J=15.0$, $\left.7.2 \mathrm{~Hz}, \mathrm{H}_{2}-12\right), 3.18\left(2 \mathrm{H}, \mathrm{d}, J=6.5 \mathrm{~Hz}, \mathrm{H}_{2}-18\right), 2.30$ (1H, sept, $J=6.5 \mathrm{~Hz}, \mathrm{H}-$ 19), 1.89 ( $\left.2 \mathrm{H}, \mathrm{qd}, J=7.2,3.0 \mathrm{~Hz}, \mathrm{H}_{2}-10\right), 1.78$ and 1.70 ( $3 \mathrm{H}$ each, s, $\mathrm{H}_{3}-16$, $\left.\mathrm{H}_{3}-15\right), 1.08\left(3 \mathrm{H}, \mathrm{t}, J=7.8 \mathrm{~Hz}, \mathrm{H}_{3}-11\right), 1.04\left(6 \mathrm{H}, \mathrm{d}, J=6.5 \mathrm{~Hz}, \mathrm{H}_{3}-20, \mathrm{H}_{3}\right.$ $21) ;{ }^{13} \mathrm{C}-\mathrm{NMR}\left(75 \mathrm{MHz}, \mathrm{CDCl}_{3}\right) \delta: 206.7,166.6,160.5,159.6,159.5,155.2$ and $132.9(\mathrm{C}, \mathrm{C}-17, \mathrm{C}-7, \mathrm{C}-2, \mathrm{C}-5, \mathrm{C}-4, \mathrm{C}-8 \mathrm{a}, \mathrm{C}-14), 121.6$ and $108.0(\mathrm{CH}$ C-13, C-3), 121.1, 107.2 and 104.5 (C, C-6, C-8, C-4a), 71.8 (CH, C-9), $63.0\left(\mathrm{CH}_{3}, 5-\mathrm{OMe}\right), 53.9$ and $31.1\left(\mathrm{CH}_{2}, \mathrm{C}-18, \mathrm{C}-10\right), 25.7\left(\mathrm{CH}_{3}, \mathrm{C}-15\right)$ 25.4 ( $\mathrm{CH}, \mathrm{C}-19), 23.0\left(\mathrm{CH}_{2}, \mathrm{C}-12\right), 22.7\left(\mathrm{CH}_{3}, \mathrm{C}-20, \mathrm{C}-21\right), 18.0$ and 10.5 $\left(\mathrm{CH}_{3}, \mathrm{C}-16, \mathrm{C}-11\right)$; HR-ESI-MS $\left.\mathrm{m} / \mathrm{z}: 403.2115 \mathrm{H}^{\mathrm{M}+\mathrm{H}}\right]^{+}$(Calcd for $\mathrm{C}_{23} \mathrm{H}_{30} \mathrm{O}_{6}, 403.2112$ ).

Cell Number Analysis The Sulforhodamine B assay (SRB assay) developed by the National Cancer Institute ${ }^{15)}$ was used for testing the cell number. The human cancer cells used were DLD-1, MCF-7, HeLa and NCIH460 cells along with $60 \mu \mathrm{M}$ resveratrol and $0.03 \mu \mathrm{M}$ camptothecin as positive controls.

Cell Cycle Analysis DLD-1 cells were seeded in $10 \mathrm{~cm}$ petri dish at a density of $5 \times 10$ cells $/ \mathrm{ml}$ and attached to the dish overnight at prior to exposure to test samples. The cells were exposed to the four coumarins $(1-4)$ at their $\mathrm{IC}_{50}$ concentrations or DMSO for $48 \mathrm{~h}(1: 4.7 \mu \mathrm{M}, 2: 5.3 \mu \mathrm{M}, 3: 6.5 \mu \mathrm{M}$, 4: $1.6 \mu \mathrm{M})$. Then, the media were collected and cells were harvested by trypsination. After centrifugation and wash with phosphate buffered saline (PBS), the cell pellet was resuspended in $200 \mu \mathrm{l}$ PBS and then slowly mixed with $2 \mathrm{ml}$ ice-cold ethanol $(70 \%)$. The fixed cells were stored at $-20{ }^{\circ} \mathrm{C}$ until day of FACS analysis. For FACS analysis, the cells were collected by centrifugation, washed with PBS, resuspended in $500 \mu \mathrm{l}$ PBS with $0.1 \mathrm{mg} / \mathrm{ml}$ RNAse $0.04 \mathrm{mg} / \mathrm{ml}$ propidium iodide and incubated in dark at room temperature for $30 \mathrm{~min}$. The cell cycle distribution was analysed using a flow cytometer (FACSCalibur, BD Biosciences, Denmark) and the percentages of cells within the $\mathrm{G}_{0} / \mathrm{G}_{1}, \mathrm{~S}, \mathrm{G}_{2} / \mathrm{M}$ phases of the cell cycle as well as the number of cells in subG $\mathrm{G}_{0} / \mathrm{G}_{1}$ were estimated in Modfit LT (Verity Software House, Inc.).

Acknowledgements We would like to thank DANIDA for a scholarship through the ENRECA Program to Ngoc T. N. Ngo. Financial supports from a DAAD sur-place scholarship to Ngoc T. N. Ngo are also gratefully acknowledged.

\section{References}

1) Pham H. H., "The Flora of Vietnam," Band 1, Youth Publisher, HoChiMinh, 1999, p. 356.

2) Kostermans A. J. G. H., "A Monograph of the Asiatic and Pacific Species of Mammea L. (Guttiferae)," Lembaga Pusat Penjelidikan Kehutanan, Bogor, Indonesia, 1961, p. 26.

3) Joshi B. S., Kamat V. N., Govindachari T. R., Ganguly A. K., Tetrahedron, 25, 1453-1458 (1969).

4) Thebtaranonth C., Imraporn S., Padungkul N., Phytochemistry, 20, 2305-2306 (1981).

5) Poobrasert O., Constant H. L., Beecher C. W. W, Farnsworth N. R., Kinghorn A. D., Pezzuto J. M., Cordell G. A., Santisuk T., Reutrakul V., Phytochemistry, 47, 1661-1663 (1998)

6) Mahidol C., Kaweetripob W., Prawat H., Ruchirawat S., J. Nat. Prod., 65, 757-760 (2002).

7) Prachyawarakorn V., Mahidol C., Ruchirawat S., Phytochemistry, 67, 924-928 (2006).

8) Chaturvedula V. S. P., Schilling J. K., Kingston D. G. I., J. Nat. Prod., 65, 965-972 (2002).

9) Laphookhieo S., Promnart P., Syers J. K., Kanjana-Opas A., Ponglimanontc C., Karalai C., J. Braz. Chem. Soc., 18, 1077-1080 (2007).

10) Lee K.-H., Chai H.-B., Tamez P. A., Pezzuto J. M., Cordell G. A., Win K. K., Tin-Wa M., Phytochemistry, 64, 535-541 (2003).

11) Bennett G. J., Lee H. H., Phytochemistry, 28, 967-998 (1989).

12) Tosa H., Iinuma M., Murakami K.-I., Ito T., Tanaka T., Chelladurai V., Riswan S., Phytochemistry, 45, 133-136 (1997).

13) Peres V., Nagem T. J., Phytochemistry, 44, 191-214 (1997).

14) Win N. N., Awale S., Esumi H., Tezuka Y., Kadota S., Bioorg. Med. Chem. Lett., 18, 4688-4691 (2008).

15) Skehan P., Storeng R., Scudiero D., Monks A., McMahon J., Vistica D., Warren J. T., Bokesch H., Kenney S., Boyd M. R., J. Natl. Cancer Inst., 82, 1107-1112 (1990). 